history will find this book of 151 pages very useful on three counts. The story of prehistoric research in the area is given, with mentions of some of the people who were particularly concerned; the situation as it is known to-day is summarized and attractively set out; a good bibliography is appended. Dr. van Riet Lowe has written two papers (South African J. Sci., 42; 1946), one concerned with a special bipolar technique of flaking found in the coastal Smithfield industries, and tho other suggests that there is evidence to maintain that Stellenbosch man possessed certain artistic qualities. Some chipped stone objects have been found which seem to show a feeling for symmetry. In the same journal Dr. Malan describes the distribution and chronology of the Modderpoort culture. It is suggested that the term proto-Magosian would well describe the industries belonging to this culture.

\section{Technical State Scholarships}

THe Minister of Education has now issued the regulations (Grant Regulations No. $5 A$ ) which will govern the award of technical State scholarships. These scholarships will be tenable at universitios, university colleges and institutions of further education which prepare students for degrees or equivalent qualifications. In order to be eligible for an award under theso regulations, a candidate must $(a)$ be a British subject ordinarily resident in England or Wales, $(b)$ have completed a course leading to an ordinary national certificate or diploma or a course accepted by the Minister as of equivalent standard, and be recommended for such an award by the principal of an establishment for further education, (c) have been in full-time or part-time attendance at such an establishment for a period of not less than two years immediately preceding August 1 of the year in which the award is made, and $(d)$ be under the age of twenty on July 31 in that year. Candidates will not be eligible for these awards if they are assisted by the Minister under any other body of regulations, or if they are recognized students in training colleges in respect of which the Minister pays grant.

\section{Smithsonian Institution Publications}

A Classified Lrst of Smithsonian Publications Available for Distribution, December 1, 1946, compiled by $H$. Munroe, has now been issued as Publication 3858. Applicants for the papers in this list, which are distributed gratis, except where price is given, are requested to state the grounds for their requests, as the Institution is only able to supply papers as an aid to research or studies in which applicants are especially interested. Papers listed in the series of Contributions to Knowledge and Miscellaneous Collections are not public documents, and the limited editions are distributed without charge to public libraries, educational establishments and learned societies in the United Statos and abroad, and are supplied to other institutions and to individuals at the prices indicated. The Smithsonian Report volumes and the papers reprinted from them are distributed gratuitously by the Institution to libraries and individuals throughout the world. Many of these volumes of which the Smithsonian edition is exhausted can be purchased from the Superintendent of Documents, Government Printing Office, Washington. The Institution maintains mailing lists of libraries and educational establishments but no general mailing list of individuals.
Veterinary Educational Trust : Canine Committee

A Canine Committee has been formed in connexion with the Veterinary Educational Trust, and Mr. F. W. Gentle will be its chairman with Mr. H. S. Lloyd as his deputy. Dr. W. R. Wooldridge, scientific director of the Trust, announced at the inaugural meeting of this Committee that the canine research station, now in the process of formation at Newmarket, will cost $£ 25,000$ to complete, and that $£ 20,000$ a year would be needed for conducting its activities. The Greyhound Racing Association had promised the Trust $£ 10,000$ a year for seven years for the work of the Newmarket station.

\section{New Scientific Journals}

Two new scientific journals, both published by the Elsevier Publishing Co., Inc., New York and Amsterdam, are Analytica Chimica Acta, an international journal dealing with all branches of analytical chemistry, edited by Paul E. Wenger (Geneva), published monthly, subscription 9.50 dollars per annum; and Biochimica et Biophysica A cta, an international journal of biochemistry and biophysics, with an editorial board, at an annual subscription of 9.00 dollars. We have received copies of the first numbers of both journals, which are of high standard. Papers are in English, French and German.

\section{British Herpetological Society}

Aт the inaugural meeting held on July 11, the following were elected as the first officers of the British Herpetological Society : President, Dr. Malcolm A. Smith, British Museum (Natural History); Hon. Secretary and Treasurer, Mr. Alfred Leutscher, British Museum (Natural History) and 5 St. Margaret's Court, London, E.12 ; Hon. Editor, Dr. Angus Bellairs, Department of Anatomy, London Hospital ; Members of Committee, Dr. Helen Spurway, Depart. ment of Zoology, University College, London, and Mr. H. W. Parker, British Museum (Natural History). It is proposed to hold meetings quarterly, if possible, in London; with an increase in membership from the provinces, outside meetings would also be considered.

\section{Announcements}

THE fifteenth Thomas Young Oration of the Physical Society will be delivered by Prof. F. Zernicke, of the University of Groningen; he will speak on "Diffraction and Optical Image Formation", and the lecture will be delivered at the Imperial College of Science and Technology, London, on September 24 at 5.10 p.m.

THE seventh series of post-graduate lectures of the London Section of the Oil and Colour Chemists' Association will be delivered by Sir Lawrence Bragg, who will give "A Review of Recent Advances in X-Ray Analysis". The lectures will be given at the Royal Institution, Albemarle Street, London, W.1, on Octobor 2, 9 and 16 at 6.30 p.m. Admission will be by ticket only, obtainable from H. C. Worsdall, c/o Messrs. Plastanol, Ltd., Crabtree Manorway, Belvedere, Kent.

Dr. LUIGI GorINI states that the communication entitled "Biochemistry of Escherichia coli and the Production of Penicillinase" (Nature, Sept. 6, p. 332) requires the following corrections: par. 3, last line, for "towards the acid or alkaline side" read "towards the alkaline side" ; par. 4, line 13, for "included" read "excluded"; par. 6, line 6, for "in this way" read "on the other hand". 